\title{
SANKSI TERHADAP PELAKU PENCULIKAN ANAK MENURUT NOMOR 35 TAHUN 2014 TENTANG PERLINDUNGAN ANAK DAN HUKUM ISLAM
}

\author{
Khairil Azmi Nasution \\ Fakultas Hukum Universitas Muhammadiyah Sumatera Utara \\ Email: khairilazmi@umsu.ac.id
}

\begin{abstract}
Abstrak
Permasalahan yang dikaji dalam tuisan ini adalah mengenai sanksi hukum bagi pelaku penculikan anak menurut Hukum Islam . tulisan ini bertujuan untuk mengetahui bagaimana sanksi terhadap pelaku penculikan anak dan mengetahui relevansinya dengan Undang-Undang Perlindungan Anak. Tulisan ini menggunakan pendekatan falsafi yaitu pendekatan sistematis yang didasarkan pada pemikiran ulama, juga digunakan metode content analyst (analisa isi) yaitu metode yang berusaha memaparkan kembali (merekonstruksi) kerangka pemikiran ulama terhadap persoalan yang diteliti sehingga nantinya dapat ditarik suatu kesimpulan terhadap pendapat mereka, yakni dengan menggunakan metode deduktif dan induktif. Tulisan ini menunjukkan bahwa pelaku penculikan anak tidak dikenakan hukuman had berupa potong tangan akan tetapi adalah hukuman ta'zir karena anak bukan merupakan harta sehingga tidak dapat dijadikan objek pencurian. Landasan hukumnya adalah hadis yang diriwayatkan oleh imam al-Bukhari, Muslim dan Ahmad bin Hambal yang bersumber dari Aisyah r.a juga relevan dengan Undang-Undang Perlindungan Anak.
\end{abstract}

Kata Kunci: Anak dan UUD Perlindungan.

\section{PENDAHULUAN}

Penculikan (menschenroof) merupakan suatu perbuatan mencuri atau melarikan orang lain dengan maksud-maksud tertentu baik untuk dibunuh atau dijadikan sandera. ( Kamus Bahasa Indonesia (Jakarta: Pusat Bahasa, 2008), h. 298.) Perbuatan ini termasuk tindak pidana yang memiliki pidana berat tergantung sistem hukum yang berlaku pada tiap negara. Pasal 76F dan pasal 83 Undang-Undang No. 35 tentang Perlindungan Anak menyatakan:

"Setiap Orang dilarang menempatkan, membiarkan, melakukan, menyuruh melakukan, atau turut serta melakukan penculikan, penjualan, dan / atau perdagangan Anak."

"Setiap orang yang melanggar ketentuan sebagaimana dimaksud dalam Pasal 76F dipidana dengan pidana penjara paling singkat 3 (tiga) tahun dan paling lama 15 (lima belas) tahun dan denda paling sedikit Rp60.000.000,00 (enam puluh juta rupiah) dan paling banyak Rp300.000.000,00 (tiga ratus juta rupiah)"'.

Islam sangat memperhatikan masalah penculikan demikian pula dengan perbuatan pidana lainnya dengan memasukkannya ke dalam bahasan fikih dengan sebutan fiqh al-jinayah. Hal ini adalah wajar karena salah satu tujuan dari pembentukan hukum Islam adalah untuk menjaga jiwa dan harta umat manusia. (Al-Syatibi, al-Muwaffaqat, juz 1417 H/1997 M), h. 20.)

Sebagai salah satu objek kajian dalam fikih, sebagaimana kajian dalam fikih lainnya, penculikan juga tidak luput dari adanya perbedaan pendapat. Salah satunya adalah mengenai bentuk hukuman bagi pelaku penculikan anak, apakah pelaku penculikan anak tersebut dikenakan hukuman had berupa potong tangan atau tidak. Dalam hal ini ulama berbeda pendapat.

Mazhab Syafi'i berpendapat bahwa pelaku penculikan anak tidak dikenakan hukuman had berupa potong tangan. Pendapat ini dapat dijumpai dalam kitab al-Muhazzab karya al-Syirazi sebagai berikut:

Artinya:

$$
\text { . حر ا صغير الم يقطع لانه ليس بمال فصل و إن سرق }
$$

Pasal menerangkan: jika seseorang menculik orang merdeka yang masih

kecil (anak-anak) tidaklah dipotong tangannya karena bahwasanya yang diculik itu bukan merupakan harta. (Abu Ishak Ibrahim bin Ali bin Yusuf al-Fairuz Abadi al-Syirazi, al-Muhazzab fi Fiqh al-Imam al-Syafi'i Radiya Allah 'Anhu, juz 2 Dar al-Fikr, t.th., 281)

Akan tetapi pelakunya dikenakan hukuman ta'zir. Alasan pendapat ini adalah bahwa anak kecil bukan merupakan objek pencurian karena bukan merupakan harta, sedangkan pencurian yang dikenakan hukuman had potong tangan adalah pencurian yang dilakukan terhadap harta/kekayaan sedangkan anak bukan merupakan harta/kekayaan. (Al-Syirazi, al-Muhazzab, h. 281.) 
Selain itu terdapat hadis yang bersumber dari Aisyah sebagai berikut:

$$
\text { (الثيخان و أحمدي الله عنها أنها قالت: "لم تكن اليد تقطع على عهد رسول الله صلى الله عليه وسلم في الثيء التافه" (رواه }
$$

Artinya:

Dari Aisyah r.a. bahwasanya ia berkata: tidaklah dipotong tangan seseorang pada masa Rasulullah SAW karena mencuri sesuatu yang tidak bernilai. ( al-Nawawi, al-Majmu' Syarh alMuhazzab, juz 15 Maktabah al-Irsyad, t.th, h. 256, 258.)

Hadis tersebut dipahami bahwa pencurian yang dikenakan hukuman potong tangan adalah pencurian atas sesuatu yang memiliki nilai. Jika yang dicuri tidak memiliki nilai maka tidak dijatuhi hukuman potong tangan, seperti mencuri anak kecil.

Pengertian Penculikan

Kata penculikan terambil dari kata culik yang berarti mencuri atau melarikan orang lain dengan maksud-maksud tertentu (dibunuh, dijadikan sandera) Kata penculikan sendiri berarti perihal menculik.( Kamus Bahasa Indonesia, 2008, h. 298)

Dalam Rancangan Kitab Undang-Undang Hukum Pidana dinyatakan bahwa penculikan Setiap orang yang membawa pergi orang dari tempat kediamannya atau tempat kediamannya sementara dengan maksud untuk menempatkan orang tersebut secara melawan hukum di bawah kekuasaannya atau kekuasaan orang lain atau untuk menempatkan orang tersebut dalam keadaan tidak berdaya. ( Pasal 561 Rancangan KUHP).

Penjelasan terhadap ketentuan dalam pasal ini menyatakan bahwa penculikan merupakan salah satu bentuk tindak pidana menghilangkan kemerdekaan seseorang. Berbeda dengan ketentuan sebelumnya, perampasan kemerdekaan dalam penculikan tidak dimaksudkan untuk memperdagangkan orang, tetapi secara melawan hukum untuk menempatkan orang tersebut di bawah kekuasaannya atau menyebabkan orang tersebut tidak berdaya.

Hukum dan Landasan Hukum Penculikan

Penculikan merupakan salah satu bentuk kejahatan terhadap kemerdekaan seseorang. Dalam Kitab Undang-Undang Hukum Pidan (KUHP) masalah penculikan ini diatur dalam Pasal 328 mengenai Kejahatan Terhadap Kemerdekaan Seseorang, serta Pasal 165 mengenai Kejahatan Terhadap Ketertiban Umum. Adapun bunyi kedua pasal tersebut adalah sebagai berikut:

Pasal 328

Barang siapa membawa pergi seorang dari tempat kediamannya atau tempat tinggalnya sementara dengan maksud untuk menempatkan orang itu secara melawan hukum di bawah kekuasaannya atau kekuasaan orang lain, atau untuk menempatkan dia dalam keadaan sengsara, diancam karena penculikan dengan pidana penjara paling lama dua belas tahun.

Ketentuan dalam pasal ini mengatur hukuman bagi pelaku penculikan aktif, yakni orang yang secara langsung menculik seseorang / melakukan penculikan baik untuk kepentingan sendiri maupun untuk dijual.

Pasal 165

(1) Barang siapa mengetahui ada niat untuk melakukan salah satu kejahatan berdasarkan pasal-pasal 104, 106, 107, dan 108, 110 - 113, dan 115 - 129 dan 131 atau niat untuk lari dari tentara dalam masa perang, untuk desersi, untuk membunuh dengan rencana, untuk menculik atau memperkosa atau mengetahui adanya niat untuk melakukan kejahatan tersebut dalam bab 8 dalam kitab undang-undang ini, sepanjang kejahatan itu membahayakan nyawa orang atau untuk melakukan salah satu kejahatan berdasarkan pasal- pasal 224 228, 250 atau salah satu kejahatan berdasarkan pasal-pasal 264 dan 275 sepanjang mengenai surat kredit yang diperuntukkan bagi peredaran, sedang masih ada waktu untuk mencegah kejahatan itu, dan dengan sengaja tidak segera memberitahukan hal itu kepada pejabat kehakiman atau kepolisian atau kepada orang yang terancam oleh kejahatan itu, dipidana jika kejahatan itu jadi dilakukan, dengan pidana penjara paling lama sembilan bulan atau pidana denda paling banyak empat ribu lima ratus rupiah. ( KUHP )

Ketentuan dalam pasal ini mengatur sanksi hukum terhadap pelaku penculikan pasif, yakni orang yang mengetahui dan sengaja membiarkan seseorang dalam kondisi darurat yakni sebagai korban penculikan tanpa adanya upaya untuk mencegah perbuatan itu terjadi seperti dengan melaporkannya kepada pihak yang berwajib.

\section{METODE PENELITIAN}

a. Hukuman Bagi Orang Yang Melakukan Penculikan

Pelaku penculikan diancam dengan hukuman dua belas tahun penjara sebagaimana ketentuan dalam Pasal 328 Kitab Undang-Undang Hukum 
Pidana sebagai berikut:

Pasal 328

Barang siapa membawa pergi seorang dari tempat kediamannya atau tempat tinggalnya sementara dengan maksud untuk menempatkan orang itu secara melawan hukum di bawah kekuasaannya atau kekuasaan orang lain, atau untuk menempatkan dia dalam keadaan sengsara, diancam karena penculikan dengan pidana penjara paling lama dua belas tahun,

Dalam Undang - Undang Perlindungan Anak (yakni Undang-Undang Nomor 35 tahun 2014) terdapat ketentuan mengenai hukuman bagi pelaku penculikan jika objek penculikan itu adalah anakanak. Dalam Pasal 83 Undang-Undang Perlindungan Anak disebutkan sebagai berikut:

Pasal 83

"Setiap orang yang melanggar ketentuan sebagaimana dimaksud dalam Pasal 76F dipidana dengan pidana penjara paling singkat 3 (tiga) tahun dan paling lama 15 (lima belas) tahun dan denda paling sedikit Rp60.000.000,00 (enam puluh juta rupiah) dan paling banyak Rp300.000.000,00 (tiga ratus juta rupiah)".

Melalui ketentuan dalam pasal ini dapat diketahui bahwa terhadap pelaku penculikan anak diancam dengan dua bentuk hukuman yaitu:

1. Hukuman penjara selama 3 sampai 15 tahun, dan

2. Hukuman denda, antara Rp60.000.000,00 sampai Rp300.000.000,00.

Jika penculikan itu dilakukan dengan tujuan untuk eksploitasi seperti perdagangan anak maka pelakunya dijerat dengan ketentuan Pasal 2 Undang-Undang Nomor 21 tahun 2007 tentang Penghapusan Tindak Pidana Perdagangan Orang sebagai berikut:

Pasal 2

Setiap orang yang melakukan perekrutan, pengangkutan, penampungan, pengiriman, pemindahan, atau penerimaan seseorang dengan ancaman kekerasan, penggunaan kekerasan, penculikan, penyekapan, pemalsuan, penipuan, penyalahgunaan kekuasaan atau posisi rentan, penjeratan utang, atau memberi bayaran atau manfaat walaupun memperoleh persetuujuan dari orang yang memegang kendali atas orang lain, untuk tujuan mengeksploitasi orang tersebut di wilayah negara Republik Indonesia, dipidana dengan pidana penjara paling singkat 3 (tiga) tahun dan paling lama 15 (lima belas) tahun dan pidana denda paling sedikit Rp. 120.000.000,-(Seratus dua puluh juta rupiah) dan paling banyak Rp. 600.000.000,-(Enam ratus juta rupiah).

Bagi pelaku penculikan pasif diancam dengan hukuman penjara paling lama 9 bulan sebagaimana ketentuan dalam Pasal 165 Kitab Undang-Undang Hukum Pidana di atas. Sedangkan dalam Undang-Undang Perlindungan Anak pelaku penculikan pasif dikenakan sanksi pidana penjara paling lama 5 tahun dan / atau denda paling banyak seratus juta rupiah. Hal ini sebagaimana diatur dalam Pasal 78 Undang-Undang Perlindungan Anak sebagai berikut:

Pasal 78

Setiap orang yang mengetahui dan sengaja membiarkan anak dalam situasi darurat sebagaimana dimaksud dalam Pasal 60, anak yang berhadapan dengan hukum, anak dari kelompok minoritas dan terisolasi, anak yang tereksploitasi secara ekonomi dan/atau seksual, anak yang diperdagangkan, anak yang menjadi korban penyalahgunaan narkotika, alkohol, psikotropika, dan zat adiktif lainnya (napza), anak korban penculikan, anak korban perdagangan, atau anak korban kekerasan sebagaimana dimaksud dalam Pasal 59, padahal anak tersebut memerlukan pertolongan dan harus dibantu, dipidana dengan pidana penjara paling lama 5 (lima) tahun dan/atau denda paling banyak Rp 100.000.000,00 (seratus juta rupiah).

Sanksi Terhadap Pelaku Penculikan Anak Menurut Hukum Islam

Pendapat Mazhab Syafi'i mengenai sanksi hukum terhadap pelaku penculikan anak dapat dijumpai dalam beberapa kitab fikih Mazhab Syafi'i dan kitab-kitab fikih lainnya, di antaranya adalah sebagai berikut:

a. Kitab al-Syirazi, al-Muhazzab fi Fiqh al-Imam al-Syafi'i Radiya Allah 'Anhu, karya Abu Ishak Ibrahim bin Ali bin Yusuf al-Fairuz Abadi al-Syirazi. Dalam kitab ini disebutkan sebagai berikut:

$$
\text { . حر ا صغير الم يقطع لانه ليس بمال فصل وإن سرق }
$$

Artinya:

Pasal menerangkan: jika seseorang menculik orang merdeka yang masih kecil (anak-anak) tidaklah dipotong tangannya karena

bahwasanya yang diculik itu bukan merupakan harta. (Abu Ishak Ibrahim bin Ali bin Yusuf al-Fairuz Abadi al-Syirazi, al-Muhazzab fi Fiqh al-Imam al-Syafi'i Radiya Allah 'Anhu, juz 2 ,H. 281)

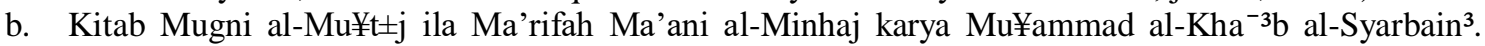
Dalam kitab ini disebutkan sebagai berikut: 
Artinya:

$$
\text { ( ولو سرق ) حرا ( صغير ا ) لا يميز أو مجنونا ... لا يقطع سارقه ( في الأصح ) }
$$

(Kalaulah seseorang menculik) orang merdeka (yang masih kecil) lagi belum mumayyiz, atau orang gila ... tidaklah dipotong tangan pelakunya (menurut pendapat yang sahih). ( Muhammad al-Kha ${ }^{-3} \mathrm{~b}$ al-Syarbain, Mugni al-Mu¥t \pm j, juz 4 , 1389 H/1978 M, h. 173.)

Dari beberapa kutipan di atas dapat diketahui bahwa menurut Mazhab Syafi'i pelaku penculikan anak tidak dikenakan hukuman had berupa potong tangan. Akan tetapi pelakunya dikenakan hukuman ta'zir. Alasan pendapat ini adalah bahwa anak kecil bukan merupakan objek pencurian karena bukan merukalan harta, sedangkan pencurian yang dikenakan hukuman had potong tangan adalah pencurian yang dilakukan terhadap harta/kekayaan sedangkan anak bukan merupakan harta/kekayaan. (Al-Syirazi, al-Muhazzab, h. 281.)

Landasan hukum yang dipergunakan oleh Mazhab Syafi'I dalam rangka mendukung pendapatnya tersebut adalah hadis berikut:

عن عائشة رضي الله عنها أنها قالت: "لم تكن اليد تقطع على عهد رسول الله صلى الله عليه وسلم في الثيء التافه" (رواه الثيخان و

Artinya:

Dari Aisyah r.a. bahwasanya ia berkata: tidaklah dipotong tangan seseorang pada masa Rasulullah SAW karena mencuri sesuatu yang tidak bernilai. (Imam al-Nawawi, al-Majmu' Syarh al-Muhazzab, juz 15 h. 256, 258.)

Hadis tersebut dipahami bahwa pencurian yang pelakunya dikenakan hukuman had berupa potong tangan adalah pencurian yang dilakukan atas sesuatu yang memiliki nilai. Jika pencurian tersebut dilakukan terhadap sesuatu yang tidak memiliki nilai maka pelakunya tidak dijatuhi hukuman had berupa potong tangan seperti mencuri anak kecil.

Demikianlah pendapat dan dalil yang dipergunakan oleh MaZhab Syafìi mengenai sanksi terhadap pelaku penculikan anak. akan dilihat bagaimana hubungannya dengan Undang-Undang Nomor 35 tahun 2014 tentang Perlindungan Anak.

\section{HASIL DAN PEMBAHASAN}

a. Analisis Berdasarkan Undang-undang Perlindungan Anak

Undang-undang No. 35 tahun 2014 tentang Perlindungan Anak, yang mulai efektif berlaku pada tanggal 18 Oktober 2014 dengan Lembaran Negara Republik Indonesia Nomor 109 dan Tambahan Lembaran Negara Republik Indonesia Nomor 5332, merupakan sebuah produk peraturan perundangundangan yang dibuat dengan tujuan untuk memberikan perlindungan hukum kepada anak terhadap segala bentuk kekerasan dan diskriminasi kepada anak, termasuk melindungi anak yang menjadi korban tindak pidana serta melindungi kepentingan-kepentingan keperdataan anak.

Sebelum adanya UU No. 35 tahun 2014 perubahan atas UU 23 TAHUN 2002 tentang Perlindungan Anak ini, di Indonesia telah berlaku UU No. 39 tahun 1999 tentang Hak Asasi Manusia yang di dalamnya terdapat pengaturan mengenai hak-hak anak serta perlindungan yang harus diberikan oleh orang tua, masyarakat, pemerintah dan Negara kepada anak, serta UU No. 3 tahun 1997 tentang Pengadilan Anak. Namun demikian, adanya undang-undang khusus mengenai perlindungan anak merupakan suatu keharusan agar upaya memberikan perlindungan serta pelaksanaan kewajjiban dan tanggung jawab tersebut memiliki landasan yuridis yang kuat.

Adapun substansi Undang-undang No. 35 tahun 20014 tentang Perlindungan Anak, secara ringkas adalah sebagai berikut:

1. Anak yang diatur dalam UU Perlindungan Anak adalah orang yang belum berusia 18 tahun, termasuk anak yang masih berada dalam kandungan Hal ini karena UU Perlindungan anak juga melindungi keperdataan anak dimana aturan ini berhubungan dengan aturan dalam Kitab Undang-Undang Hukum Perdata, yakni aturan mengenai Orang, dimana apabila kepentingan anak menghendaki, anak yang berada dalam kandungan seorang perempuan dianggap telah ada, sedangkan anak yang mati pada saat dilahirkan dianggap tidak pernah ada. Jadi Anak di dalam Undang-Undang ini diatur batasan usianya dari sejak dalam kandungan seorang perempuan hingga usia 18 tahun.

2. Penangkapan, penahanan atau pidana penjara anak hanya dilakukan sesuai dengan hukum yang berlaku dan sebagai upaya terakhir, apabila upaya lain bagi anak yang melakukan perbuatan pidana, seperti dikembalikan kepada orang tuanya, ataupun diserahkan kepada Departemen Sosial untuk dibina, tidak dapat lagi dilakukan

3. Hal-hal keperdataan Anak lain yang diatur antara lain adalah:

a. Hak dan kewajiban anak, Orang tua, Pemerintah dan Masyarakat terhadap Anak;

b. Pemberian Identitas anak dengan pencatatan kelahirannya;

c. Pencabutan kekuasaan terhadap orang tua atau kuasa asuh yang lalai, 
d. Pengasuhan dan pengangkatan anak serta perwalian;

e. Perlindungan Anak dalam beragama, kesehatan, pendidikan dan sosial Anak.

4. Sedangkan perlindungan anak dalam perkara pidana dikategorikan sebagai perlindungan khusus yang membutuhkan perlakuan khusus dalam penanganan perkaranya.

5. Aturan pidana bagi pelaku tindak pidana kepada anak adalah sebagai berikut:

a. Penjatuhan hukuman kepada para pelaku tindak pidana yang telah melakukan perbuatan pidana pada anak, akan dijatuhi sanksi pidana yang lebih berat;

b. Undang-Undang Perlindungan Anak, mengatur ketentuan pidana bagi pelaku tindak pidana pada anak dalam perkara:

1) Diskriminasi dan penelantaran anak;

2) Sengaja membiarkan anak dalam situasi darurat, sengaja membiarkan anak terlibat dalam masalah hukum,menjadi minoritas dan terisolasi, tereksploitasi seksual dan / atau ekonomi, diperdagangkan, menjadi korban narkotik, alkohol, psikotropika dan zat aditif lain, padahal anak tersebut membutuhkan pertolongan dan perlu dibantu;

3) Pengangkatan anak illegal;

4) Penganiayaan terhadap anak;

5) Perkosaan terhadap anak; perbuatan cabul terhadap anak;

6) Memperdagangkan atau menculik anak;

7) Transplantasi organ anak illegal;

8) Jual beli organ/jaringan anak illegal;

9) Pemaksaan masuk ke suatu agama;

10) Perekrutan militer anak;

11) Mengekspolitasi ekonomi atau seksual anak;

12) Melibatkan anak dalam penyalahgunaan narkoba.

c. Undang-Undang Perlindungan Anak juga mengatur mengenai penentuan minimal ancaman hukuman bagi perbuatan pidana yang menyebabkan anak-anak sebagai korban dalam pidana perkosaan, pencabulan, perdagangan / penculikan anak, dan sengaja melibatkan anak dalam penyalahgunaan narkoba

6. Anak sebagai Korban Kekerasan di dalam Rumah Tangga. Pada dasarnya berlakunya UndangUndang No 35 Tahun 2004 mengenai Penghapusan Kekerasan dalam Rumah Tangga yang menempatkan Anak juga sebagai salah satu subyek yang dilindungi dalam Undang-Undang ini tidak menghapus keberadaan Undang-Undang Perlindungan Anak yang telah ada. Namun jika dicermati, maka UU KDRT ini memberikan perlindungan yang lebih bagi anak pada beberapa hal, terutama bagi anak yang mendapatkan perlakuan kekerasan baik secara fisik maupun psikis oleh orang yang ada dalam rumah tangga si anak, masih ditambah lagi anak mendapatkan hakhak lain untuk mendapatkan perlindungan bukan hanya dari pemerintah namun juga dari masyarakat.

Mengenai penculikan terhadap anak, Undang-Undang Perlindungan Anak menekankan bahwa:

1. Anak korban penculikan harus mendapatkan perlindungan khusus termasuk hak-haknya melalui upaya pengawasan, perlindungan, pencegahan, perawatan, dan rehabilitasi oleh pemerintah dan masyarakat. Hal ini sebagaimana terdapat dalam Pasal 59 sebagai berikut:

"Pemerintah, Pemerintah Daerah, dan lembaga negara lainnya berkewajiban dan bertanggung jawab untuk memberikan Perlindungan Khusus kepada Anak. (2) Perlindungan Khusus kepada Anak sebagaimana dimaksud pada ayat (1) diberikan kepada: a. Anak dalam situasi darurat; b. Anak yang berhadapan dengan hukum; c. Anak dari kelompok minoritas dan terisolasi; d. Anak yang dieksploitasi secara ekonomi dan/atau seksual; e. Anak yang menjadi korban penyalahgunaan narkotika, alkohol, psikotropika, dan zat adiktif lainnya; f. Anak yang menjadi korban pornografi; g. Anak dengan HIV/AIDS; h. Anak korban penculikan, penjualan, dan/atau perdagangan; i. Anak korban Kekerasan fisik dan/atau psikis; j. Anak korban kejahatan seksual; k. Anak korban jaringan terorisme; 1. Anak Penyandang Disabilitas; m. Anak korban perlakuan salah dan penelantaran; $n$. Anak dengan perilaku sosial menyimpang; dan o. Anak yang menjadi korban stigmatisasi dari pelabelan terkait dengan kondisi Orang Tuanya.

Bentuk perlindungan khusus terhadap anak yang menjadi korban penculikan adalah dilakukan melalui upaya pengawasan, perlindungan, pencegahan, perawatan, dan rehabilitasi oleh pemerintah dan masyarakat. Hal ini sebagaimana diatur dalam Pasal 68 ayat (1) sebagai berikut:

Pasal 68

Perlindungan Khusus bagi Anak korban penculikan, penjualan, dan/atau perdagangan sebagaimana dimaksud dalam Pasal 59 ayat 2 huruf h dilakukan melalui upaya pengawasan, perlindungan, pencegahan, perawatan, dan rehabilitasi 
Terhadap, pelaku penculikan anak terdapat dua ketentuan pidana:

a. Pelaku penculikan pasif, yakni orang yang mengetahui dan sengaja membiarkan anak dalam kondisi darurat, yakni anak sebagai korban penculikan. Sanksi terhadap pelaku penculikan pasif adalah pidana pidana paling lama 15 tahun dan/atau denda paling banyak Tiga Ratus juta rupiah. Hal ini sebagaimana tercantum dalam Pasal 83 sebagai berikut:

Setiap orang yang melanggar ketentuan sebagaimana dimaksud dalam Pasal 76F dipidana dengan pidana penjara paling singkat 3 (tiga) tahun dan paling lama 15 (lima belas) tahun dan denda paling sedikit Rp60.000.000,00 (enam puluh juta rupiah) dan paling banyak Rp300.000.000,00 (tiga ratus juta rupiah).

b. Pelaku penculikan aktif, yakni orang yang secara langsung menculik anak baik untuk kepentingan dirinya sendiri maupun untuk dijual. Sanksi terhadap pelaku penculikan aktif adalahpidana penjara antara 15 sampai 3 tahun dan denda antara tiga ratus juta rupiah sampai enam puluh juta rupiah. Hal ini sebagaimana tercantum dalam Pasal 83 sebagai berikut:

Pasal 83

"Setiap orang yang memperdagangkan, menjual, atau menculik anak untuk diri sendiri atau untuk dijual, dipidana dengan pidana penjara paling lama 15 (lima belas) tahun dan paling singkat 3 (tiga) tahun dan denda paling banyak Rp 300.000.000,00 (tiga ratus juta rupiah) dan paling sedikit Rp 60.000.000,00 (enam puluh juta rupiah)"

Selain Undang-undang No. 35 tahun 2014 tentang Perlindungan Anak, di Indonesia terdapat 4 peraturan perundang-undangan penting lainnya yang terkait dengan upaya pemerinyah dalam memberikan perlindungan kepada anak-anak, termasuk dari upaya penculikan, yakni Konvensi Hak Anak, Kitab Undang-undang Hukum Pidana, Undang-undang No. 39 tahun 1999 tentang Hak Asasi Manusia, dan Undang-undang No 21 Tahun 2007 tentang Penghapusan Tindak Pidana Perdagangan Orang.

1. Konvensi Hak Anak

Secara historis, perumusan naskah Konvensi Hak Anak dimulai sejak tahun 1979, dan dalam waktu 10 tahun kemudian, tepatnya pada 20 November 1989, naskah akhir konvensi dapat diterima dan disetujui dengan suara bulat oleh Majelis Umum PBB. Sesuai ketentuan Pasal 49 ayat 1, Konvensi Hak Anak diberlakukan sebagai hukum HAM internasional pada 2 September 1990.

Indonesia meratifikasi Konvensi Hak Anak melalui Keputusan Presiden No. 36 tahun 1990 tertanggal 25 Agustus 1990. Dengan ratifikasi tersebut, Indonesia secara teknis telah dengan sukarela mengikatkan diri pada ketentuan-ketentuan yang terkandung dalam Konvensi Hak Anak. Sesuai dengan Pasal 49 ayat 2, Konvensi Hak Anak dinyatakan berlaku di Indonesia sejak tanggak 5 Oktober 1990.

Pada Pasal 11 Konvensi Hak Anak terdapat penekanan bahwa negara berkewajiban memberantas pengiriman anak ke luar negeri dan tidak dikembalikan secara sah termasuk anakanak yang diculik. Bunyi Pasal 11 Konvensi Hak Anak adalah sebagai berikut:

Pasal 11

(1) Pihak Negara harus mengambil langkah-langkah untuk memberantas pengiriman anak ke luar negri dan tidak dikembalikan secara tidak sah.

(2) Pada akhirnya, Pihak Negara harus meningkatkan kesimpulan perjanjian bilateral dan multilateral atau pencapaian perjanjian yang ada. Pasal 35

Demikian pula pada Pasal 35 Konvensi Hak Anak yang berbunyi sebagai berikut:

Pihak Negara akan mengambil langkah-langkah tepat secara nasional, bilateral dan multilateral untuk mencegah penculikan, penjualan atau perdagangan anak untuk tujuan apapun atau dalam bentuk apapun.

Kedua pasal tersebut menunjukkan adanya kewajiban bagi Negara untuk mencegah dan menanggulangi penculikan atau penyimpanan anak-anak di luar negeri oleh orang tua atau pihak ketiga, serta melakukan setiap upaya untuk mencegah penjualan, perdagangan dan penculikan anak. Pengaturan ini kemudian dijadikan konsideran dalam pemikiran perlindungan bagi anak melalui UU Perlindungan Anak No 35 Tahun 2014.

2. KUHP

Kejahatan penculikan menurut Kitab Undang-Undang Hukum Pidana sebagai tindakan yang membawa pergi seseorang dari kediamannya untuk keterlibatan dalam perbuatan melawan 
hukum, atau di bawah kekuasaan orang lain atau yang bertujuan untuk menyengsarakan. Perbuatan ini diancam dengan hukuman penjara selama-kamanya dua belas tahun sebagaimana ketentuan dalam Pasal 328 Kitab Undang-Undang Hukum Pidana sebgai berikut:

Pasal 328

Barang siapa membawa pergi seorang dari tempat kediamannya atau tempat tinggalnya sementara dengan maksud untuk menempatkan orang itu secara melawan hukum di bawah kekuasaannya atau kekuasaan orang lain, atau untuk menempatkan dia dalam keadaan sengsara, diancam karena penculikan dengan pidana penjara paling lama dua belas tahun.

3. Undang-undang No. 39 tahun 1999 tentang Hak Asasi Manusia

Pasal 65 Undang-undang No. 39 tahun 1999 tentang Hak Asasi Manusia memberikan jaminan perlindungan kepada anak dari setiap tindakan eksploitasi dan pelecehan seksual, penculikan, perdagangan anak, serta dari berbagai bentuk penyalahgunaan narkotika, psikotropika, dan zat adiktif lainnya. Selengkapnya pasal ini berbunyi sebagai berikut:

Pasal 65

"Setiap anak berhak untuk memperoleh perlindungan dari kegiatan eksploitasi dan pelecehan seksual, penculikan, perdagangan anak, serta dari berbagai bentuk penyalahgunaan narkotika, psikotropika, dan zat adiktif lainnya."

4. UU No 21 Tahun 2007 tentang Penghapusan Tindak Pidana Perdagangan Orang

Menurut UU No 21 Tahun 2007 tentang Penghapusan Tindak Pidana Perdagangan Orang, penculikan merupakan salah satu cara dalam melakukan perdagangan orang yang bertujuan untuk eksploitasi atau yang mengakibatkan orang tersebut tereksploitasi, termasuk dalih pengangkatan anak. Hal ini dapat dipahami dari Pasal 1 poin 1 dan Pasal 2 ayat (1) sebagai berikut:

Pasal 1

Dalam Undang-Undang ini yang dimaksud dengan :

1. Perdagangan Orang adalah tindakan perekrutan, pengangkutan, penampungan, pengiriman, pemindahan, atau penerimaan seseorang dengan ancaman kekerasan, penggunaan kekerasan, penculikan, penyekapan, pemalsuan, penipuan dan penyalahgunaan kekuasaan atau posisi rentan, penjeratan uang atau memberikan bayaran atau manfaat, sehingga memperoleh persetujuan dari orang yang memegang kendali atas orang lain tersebut, baik yang dilakukan di dalam negara maupun antar negara, untuk tujuan ekspolitasi atau mengakibatkan orang tereksploitasi.

Pasal 2

(1) Setiap orang yang melakukan perekrutan, pengangkutan, penampungan, pengiriman, pemindahan, atau penerimaan seseorang dengan ancaman kekerasan, penggunaan kekerasan, penculikan, penyekapan, pemalsuan, penipuan, penyalahgunaan kekuasaan atau posisi rentan, penjeratan utang, atau memberi bayaran atau manfaat walaupun memperoleh persetuujuan dari orang yang memegang kendali atas orang lain, untuk tujuan mengeksploitasi orang tersebut di wilayah negara Republik Indonesia, dipidana dengan pidana penjara paling singkat 3 (tiga) tahun dan paling lama 15 (lima belas) tahun dan pidana denda paling sedikit Rp. 120.000.000,-(Seratus dua puluh juta rupiah) dan paling banyak Rp. 600.000.000,-(Enam ratus juta rupiah).

\section{KESIMPULAN}

Dari beberapa peraturan tersebut ada elemen tujuan, yang menjadi catatan yakni bahwa penculikan telah mengakibatkan korban menjadi sengsara atau dieksploitasi karena itu diluar kehendak dan keinginan korban. Oleh karenanya, sudah sewajarnya pelaku kejahatan ini diancam dengan ancaman hukuman yang berat.

Penutup

Jika dicermati maka terlihat bahwa ternyata perlakuan hukum terhadap pelaku penculikan berbeda dengan pelaku pencurian. Yang mana jelas bahwa pencurian hanya melibatkan harta benda seseorang sedangkan penculikan sudah melibatkan jiwa dan kemerdekaan seseorang. Oleh karenanya sudah sangat wajar bila Undang-Undang menetapkan keterlibatan negara dalam menangani korban penculikan, apalagi yang menjadi korbannya adalah anak-anak karena akan mengakibatkan trauma atau paling tidak dapat mempengaruhi mental anak.

Melihat uraian di atas maka dengan berusaha seobyektif mungkin penulis berkesimpulan bahwa Hukum Islam sangat relevan mengenai sanksi terhadap pelaku penculikan anak dengan kondisi hukum 
di Indonesia adalah, dengan alasan bahwa di Indonesia hukuman bagi pelaku penculikan adalah tidak sama dengan hukuman bagi pelaku pencurian.

\section{DAFTAR PUSTAKA}

Al-Syatibi. al-Muwaffaqat. Juz 1. t.t.: Dar Ibn Affan, 1417 H/1997 M.

al-Daruqutni, Ali bin Umar Abu al-Hasan. Sunan al-Daru Qutni. Juz 3. Beirut: Dar al-Ma'rifah, 1386 H / $1966 \mathrm{M}$.

Departemen Agama Republik Indonesia. al-Qur`an dan Terjemahnya. Semarang: Karya Toha Putra, t.th.. Dewan Redaksi Ensiklopedi Islam. Ensiklopedi Islam. Jakarta: Ichtiar Baru van Hoevem 2001.

Hazm, Abu Muhammad Ali bin Ahmad bin Said bin. al-Muhalla. Jilid 8. Juz 11. t.t.: Dar al-Fikr, t.th..

'Itr, Nur al-Din. Manhaj fi Ulum al-Hadis. Diterjemahkan oleh Mujiyo. Cet.ke-2. Bandung: Remaja Rosdakarya Offset, 1997.

al-Khatib, Ajjaj. Usul al-Hadis.. Diterjemahkan oleh Qadirun Nur dan Ahmad Musyafiq. Jakarta: Gaya Media Pratama, 2003.

al-Nawawi, Imam. al-Majmu' Syarh al-Muhazzab. Juz 15. Jeddah: Maktabah al-Irsyad, t.th.

PM Abdullah. Abd-allah.blogspot/sejarah/zhahiriyah/co.id. Diakses pada tanggal 35 Desember 2009.

Pusat Bahasa Departemen Pendidikan Nasional. Kamus Bahasa Indonesia. Jakarta: Pusat Bahasa, 2008.

Shiddieqi, TM Hasbi Ash. Pokok-pokok Ilmu Dirayah Hadis. Jilid 1. Jakarta: Bulan Bintang, 1987.

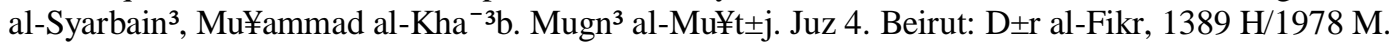

al-Syirazi, Abu Ishak Ibrahim bin Ali bin Yusuf al-Fairuz Abadi. al-Muhazzab fi Fiqh al-Imam al-Syafi'i Radiya Allah 'Anhu. Juz 2. Libanon: Dar al-Fikr, t.th.. 